\title{
Characteristics of reproductive traits and egg traits of crossbred geese with Graylag ancestry*
}

\author{
A. Mazanowski ${ }^{1,3}$, Z. Bernacki ${ }^{1}$ and T. Kisiel ${ }^{2}$ \\ ${ }^{I}$ Department of Poultry Breeding, University of Technology and Agriculture \\ Mazowiecka 28, 85-084 Bydgoszcz, Poland \\ ${ }^{2}$ Department of Poultry Breeding, National Research Institute of Animal Production \\ Dworzyska 1, 62-035 Kórnik, Poland
}

(Received 25 June 2004; revised version 22 April 2005; accepted 4 August 2005)

\begin{abstract}
The aim of this study was to evaluate the reproductive traits and physical traits of the eggs of three-breed crosses of geese - White Kołuda $(\mathrm{WK}) \times$ Slovakian $(\mathrm{Sl}) \times$ Graylag $(\mathrm{Gr})-$ in terms of the direction of crossing of the parents, and to determine differences in the chemical composition of eggs at the beginning and at the end of the reproductive period. The highest egg production (37 eggs), egg weight (192.4 g) and body weight (males $7491 \mathrm{~g}$, females $6507 \mathrm{~g}$ ) were characteristic of the crossbreds Sl'GrWK. The eggs of these geese had high density and a high yolk index, as well as a higher Haugh unit value, compared to those of geese from the other groups. The mutually crossed hybrids WKGr'Sl, which had the lowest body weight (males $5804 \mathrm{~g}$, females $5763 \mathrm{~g}$ ), had the highest egg fertility (77.3\%) and hatchability of goslings from set (67.1\%) and fertilized eggs $(86.9 \%)$. In addition, they had the highest Haugh unit value and the greatest number of pores in the shell. The egg yolks of WKGr'Sl crossbreds contained the highest amount of ash at the end of egg production and the highest amount of water in albumen at the beginning of egg production. During the egg production period, water and ash content increased, and the fat content of the egg yolks of the geese decreased regardless of the direction of crossing of the parents. A statistically significant interaction (time $\times$ groups) occurred only for percentage of ash in yolk. During the same period, the levels of water, protein and ash increased in the albumen of the eggs, but time $\times$ groups interactions were only found for water and ash percentage.
\end{abstract}

KEY WORDS: goose, crossbred, reproductive traits, egg traits, composition of egg

\footnotetext{
* This work was conducted as part of statutory activity of the National Research Institute of Animal Production, Project No. 1506.2

${ }^{3}$ Corresponding author: e-mail: katdrob@atr.bydgoszcz.pl
} 


\section{INTRODUCTION}

In the search for geese characterized by good muscling and low fatness of carcasses, attention has been paid to crosses of domestic geese with wild Graylag geese (Mazanowski and Chełmońska, 2000; Mazanowski, 2001; Mazanowski et al., 2002; Mazanowski and Bernacki, 2003; Mazanowski and Dziadek, 2003). Crosses of domestic and wild geese have attracted increasing interest in Western Europe, resulting from the search for safe food with the characteristics of the meat of wild birds.

The commercial production of White Kołuda $\times$ wild geese is hindered by their low egg production of 24 to 26 eggs (Mazanowski and Chełmońska, 2000). Therefore an attempt was made to increase their egg production by crossing two-breed hybrids with Slovakian geese, which are characterized by very good reproductive parameters. Wild Graylag geese show low egg production but considerable egg weight, which complies with the Polish Standard (1998). In studies by Mazanowski and Bernacki (2003) and Mazanowski and Dziadek (2003), three-breed crosses were characterized by greater egg production than in this study, from 29 to 41 eggs per goose.

The use of wild Graylag geese for the creation of three-breed crosses may have a positive effect on the physical traits and chemical components of the eggs of the hybrids, and thus their value as organic food (in some Western European countries goose eggs are considered a delicacy). Goose eggs have been evaluated sporadically for physical traits (Puchajda, 1991; Ramos et al., 1991; Rosiński, 2000; Mazanowski and Adamski, 2002) and very occasionally for some chemical components (Ramos et al., 1991; Puchajda, 1995; Romanov, 1999; Rosiński, 2000). This is one of the reasons justifying the breeding work in this area.

The aim of the present experiment was to evaluate the reproductive and physical traits of eggs from three-breed crosses of White Koluda $\times$ Slovakian $\times$ Graylag geese as related to the direction of crossing of the parents and to determine differences in the chemical composition of eggs at the beginning and at the end of the reproductive period.

\section{MATERIAL AND METHODS}

The study was carried out in 2003 at the Dworzyska Waterfowl Breeding Farm, belonging to the National Research Institute of Animal Production (Poland). Reproductive traits, body weight, egg structure and chemical composition were investigated in 4-year-old three-breed crosses of geese (Graylag $\times$ White Kołuda $\times$ Slovakian). Each group contained $4-6$ gandersand 12-21 geese to maintain the 
1:3-4 sex ratio throughout the experiment. Ganders and geese within a group were similar, and the groups differed in the direction of crossing. The crossbreeding scheme and symbols of geese are given in Table 1.

TABLE 1

The crossbreeding scheme and symbols of geese

\begin{tabular}{|c|c|c|c|c|c|}
\hline \multirow{2}{*}{ Group } & \multicolumn{2}{|c|}{ Symbols of geese - sex } & \multicolumn{2}{|c|}{ No of geese - sex } & \multirow{2}{*}{$\begin{array}{c}\text { Proportion } \\
\text { of males to females }\end{array}$} \\
\hline & males & females & males & females & \\
\hline I & GrWK'S1 & GrWK'Sl & 6 & 21 & 3.5 \\
\hline II & Sl'GrWK & Sl'GrWK & 6 & 21 & 3.5 \\
\hline III & WKGr'S1 & WKGr'Sl & 4 & 12 & 3.0 \\
\hline IV & $\mathrm{Sl}^{\prime} \mathrm{WKGr}$ & Sl'WKGr & 5 & 20 & 4.0 \\
\hline
\end{tabular}

Gr - Graylag goose (Anser anser L.), WK - White Kołuda goose, S1 - Slovakian goose

Throughout reproduction, the geese were kept outdoors in pens bedded with rye straw and were fed on an ad libitum basis. Crude protein in feed was 18.3\% and metabolizable energy $2830 \mathrm{kcal}(11.8 \mathrm{MJ})$ per $\mathrm{kg}$. During the reproductive period, vitamin preparations were added to each $100 \mathrm{~kg}$ of feed $(25 \mathrm{~g}$ Polfamix $\mathrm{Z}$ and $10 \mathrm{~g}$ Polfasol B compositum) and, separately, a mineral mix for poultry, limestone and gravel at a 1:1:4 ratio by volume. The birds were vaccinated against Derzsy disease 30 days before the start of lay.

The number of eggs was recorded daily in groups from the start to the end of lay. Once a week, all hatching eggs were individually weighed. Throughout reproduction, the amounts of feed given were recorded each week. Percentages of fertilized eggs and hatchability of goslings were evaluated at weekly intervals throughout the reproductive period. Incubation of eggs and hatches of goslings were performed in Petersime walk-in incubators. Ganders and geese were individually weighed before and after the end of egg production.

The weight and traits of eggshell and egg content were evaluated once at the 8th week of egg production using 12 eggs from each group, $24 \mathrm{~h}$ after laying. Mean egg weight, egg shape index (egg width to length ratio in \%) and egg area were calculated using the formula of Paganelli et al. (1974):

$$
\mathrm{P}_{\mathrm{s}}=4.835 \times \mathrm{M}^{0.662} \text {, where } \mathrm{M}=\text { egg weight }
$$

Shell colour was determined using a Quality Control Reflectometer (QCR) from the TSS (Technical Services and Supplies) kit. Shell strength was measured with an Egg Crusher EGC 20 SW (VEIT). Shell deformation was determined using a Marius instrument. Shell was dried for three hours at $105^{\circ} \mathrm{C}$ and weighed, and shell thickness was measured with a digital micrometer screw. Shell density was measured with a kit for determining the density of solid bodies, and distilled water $\left(25^{\circ} \mathrm{C}\right)$ was used as the model liquid. 
Eggshell fragments from the large end, small end and the equator of the egg were cooked for $5 \mathrm{~min}$ in $5 \% \mathrm{NaOH}$ solution to remove the protein fraction from the outer and inner shell surface. After cooking, the shells were rinsed in distilled water, dried, immersed for $5 \mathrm{sec}$ in diluted $65 \%$ nitrogen acid (one part acid to three parts water) and rinsed again in distilled water. Dried fragments of the shells were coated with methylene blue on their inner side. Shell porosity was read under a stereoscopic microscope at $4 \times$ magnification (Nikon) to determine the number of pores per $0.25 \mathrm{~cm}^{2}$ of shell surface.

White and yolk were isolated, and yolk was weighed. White weight was calculated from the difference between egg weight and yolk and shell weights. Percentages of yolk, white and shell were compared with the weight of fresh egg. Yolk and white density were examined with a liquid density determination kit and $\mathrm{pH}$ with a CP-401 pH-meter (Elmetron), and height of thick white and yolk $(\mathrm{mm})$ were measured with a QCD (Quality Control Digital Display Unit) instrument (TSS). Yolk diameter ( $\mathrm{mm}$ ) was determined along the chalaza using electronic calipers. The yolk height to yolk diameter ratio (\%) was used as the yolk index.

Haugh units were calculated according to the formula given by Wiliams (1997):

$$
\mathrm{HU}=100 \lg \left(\mathrm{H}+7.7-1.7 \mathrm{M}^{0.37}\right)
$$

where $\mathrm{H}=$ height of thick white, $\mathrm{M}=$ egg weight.

Yolk colour was determined on a 15-point La Roche scale. Blood and meat spots were recorded.

At the start (week 2) and at the end (week 14) of egg laying, 12 eggs were taken from each group for chemical analyses. After removing and separating yolk and white, their chemical composition including crude protein, fat and water and ash was determined using the standard methods.

The results were analysed statistically using computer programs developed at the National Research Institute of Animal Production (Kiełczewski, 1992).

\section{RESULTS}

The greatest egg production and egg weight were characteristic of Sl'GrWK crosses. In the other groups, egg production and egg weight were lower and similar (Table 2). Crossbred ganders Sl'GrWK and Sl'WKGr derived from Slovakian ganders and White Kołuda $\times$ Graylag geese were significantly heavier prior to reproduction than ganders from the other groups. During reproduction, body weight loss in ganders did not exceed $10 \%$. The highest body weight was 
TABLE 2

Egg production, egg wright and body wright in geese

\begin{tabular}{lccccc}
\hline \multirow{2}{*}{ Trait } & \multicolumn{4}{c}{ Cross of geese } & \multirow{2}{*}{ SEM } \\
\cline { 2 - 5 } & GrWK'Sl & Sl'GrWK & WKGr'S1 & Sl'WKGr & \\
\hline Number of eggs per goose & $32^{\mathrm{b}}$ & $37^{\mathrm{a}}$ & $32^{\mathrm{b}}$ & $31^{\mathrm{b}}$ & 1.55 \\
Egg weight, g & $186.3^{\mathrm{b}}$ & $192.4^{\mathrm{a}}$ & $182.6^{\mathrm{b}}$ & $182.5^{\mathrm{b}}$ & 1.87 \\
$\begin{array}{l}\text { Ganders - body weight, g } \\
\quad\end{array}$ & & & & & \\
$\quad$ before reproduction & $6461^{\mathrm{ab}}$ & $7491^{\mathrm{a}}$ & $5804^{\mathrm{b}}$ & $7106^{\mathrm{a}}$ & 418 \\
$\quad$ after reproduction & 6057 & 6950 & 6085 & 6515 & 463 \\
Geese - body weight, g & & & & & \\
$\quad$ before reproduction & $6315^{\mathrm{ab}}$ & $6507^{\mathrm{a}}$ & $5763^{\mathrm{b}}$ & $6323^{\mathrm{ab}}$ & 221 \\
$\quad$ after reproduction & $5452^{\mathrm{a}}$ & $5601^{\mathrm{a}}$ & $4589^{\mathrm{b}}$ & $5203^{\mathrm{ab}}$ & 205 \\
\hline
\end{tabular}

Gr - Graylag goose (Anser anser L.), WK - White Kołuda goose, S1 - Slovakian goose

SEM - standard error of means

ab - mean values in rows followed by different letters differ significantly $(\mathrm{P}<0.05)$

found in the geese from group II prior to reproduction and by the geese from groups I and II after the end of reproduction. During reproduction body weight loss was much greater (up to 20\%) in geese than in ganders.

The greatest egg fertilization was noted in groups WKGr'Sl and Sl'GrWK. In groups GRWK'S1 and S1'WKGr, egg fertilization was significantly lower than in the other groups (Table 3). Percentages of unhatched goslings were greater in groups Sl'GrWK and Sl'WKGr than in groups GrWK'SL and WKGr'Sl. Percentages of gosling hatchability from fertilized eggs were high in all the groups, with the highest percentages of hatchability from set and fertilized eggs in group WKGr'Sl.

TABLE 3

Egg hatch and hatchability of goslings ${ }^{1}$

\begin{tabular}{lcccc}
\hline \multirow{2}{*}{ Trait } & \multicolumn{4}{c}{ Cross of geese } \\
\cline { 2 - 5 } & GrWK'Sl & Sl'GrWK & WKGr'Sl & Sl'WKGr \\
\hline Fertilized eggs, \% & 34.1 & 47.2 & 77.2 & 29.2 \\
Dead embryos, \% & 5.5 & 3.1 & 3.3 & 6.8 \\
& & & & \\
Goslings, \% & & & 7.8 & 16.0 \\
$\quad$ unhatched & 9.0 & 16.3 & 2.0 & 0.6 \\
$\quad$ crippled and weak & 1.0 & 1.0 & 67.1 & 22.3 \\
$\quad$ healthy from set eggs & 28.8 & 37.6 & 86.9 & 76.6 \\
$\quad$ healthy from fertilized eggs & 84.5 & 79.6 & 21 & 7 \\
Healthy goslings per goose, head & 9 & 14 & & \\
\hline
\end{tabular}

${ }^{1}$ statistical analysis was not performed 
Egg weight and eggshell area determined at the peak of egg production were highest in group GrWK'Sl and lowest in group Sl'WKGr. The other shell traits (index, thickness, deformation, strength and colour expressed as percentage of white) did not differ statistically among the groups, and nor did percentages of yolk, protein and shell in egg (Table 4). Significant differences among the groups were only found in yolk density. No statistically significant differences were found between the groups in white or shell density.

TABLE 4

Egg quality parameters (8 week of laying)

\begin{tabular}{|c|c|c|c|c|c|}
\hline \multirow{2}{*}{ Trait } & \multicolumn{4}{|c|}{ Cross of geese } & \multirow{2}{*}{ SEM } \\
\hline & GrWK'Sl & Sl'GrWK & WKGr'Sl & Sl'WKGr & \\
\hline Egg weight, g & $182.4^{\mathrm{a}}$ & $182.1^{\mathrm{ab}}$ & $179.2^{\mathrm{ab}}$ & $172.1^{\mathrm{b}}$ & 3.50 \\
\hline Egg shape index, \% & 67.1 & 67.7 & 67.4 & 66.5 & 0.70 \\
\hline Shell area, $\mathrm{cm}^{2}$ & $151.7^{\mathrm{a}}$ & $151.5^{\mathrm{ab}}$ & $150.0^{\mathrm{ab}}$ & $146.0^{\mathrm{b}}$ & 1.94 \\
\hline Shell thickness, mm & 0.611 & 0.604 & 0.605 & 0.579 & 0.01 \\
\hline Shell deformation, $\mu \mathrm{m} / \mathrm{cm}^{2}$ & 15.0 & 15.4 & 14.7 & 14.7 & 0.75 \\
\hline Shell resistance, $\mathrm{N}$ & 20.8 & 20.4 & 17.0 & 21.3 & 1.97 \\
\hline Shell colour, $\%$ of white & 76.0 & 77.2 & 76.8 & 77.8 & 1.39 \\
\hline \multicolumn{6}{|l|}{ Proportion of egg, \% } \\
\hline yolk & 34.6 & 35.9 & 35.2 & 34.8 & 0.68 \\
\hline albumen & 53.7 & 52.4 & 53.3 & 54.1 & 0.74 \\
\hline shell & 11.7 & 11.7 & 11.5 & 11.1 & 0.23 \\
\hline \multicolumn{6}{|l|}{ Density, $\mathrm{g} / \mathrm{cm}^{3}$} \\
\hline yolk & $0.412^{\mathrm{ab}}$ & $0.431^{\mathrm{a}}$ & $0.405^{\mathrm{b}}$ & $0.402^{b}$ & 0.01 \\
\hline albumen & 0.360 & 0.362 & 0.348 & 0.367 & 0.01 \\
\hline shell & 2.054 & 2.082 & 2.103 & 2.095 & 0.02 \\
\hline Yolk colour & 4.0 & 3.9 & 3.7 & 3.6 & 0.27 \\
\hline Yolk index, \% & $33.5^{\mathrm{a}}$ & $33.4^{\mathrm{a}}$ & $31.8^{\mathrm{ab}}$ & $30.7^{\mathrm{b}}$ & 0.71 \\
\hline Haugh units & $37.9^{\mathrm{c}}$ & $43.0^{\mathrm{a}}$ & $43.9^{\mathrm{a}}$ & $39.9^{\mathrm{b}}$ & 7.49 \\
\hline \multicolumn{6}{|l|}{ Mean values of $\mathrm{pH}$} \\
\hline yolk & $6.22^{\mathrm{a}}$ & $6.16^{\mathrm{b}}$ & $6.11^{\mathrm{b}}$ & $6.14^{\mathrm{b}}$ & 0.02 \\
\hline albumen & $8.89^{\mathrm{a}}$ & $8.75^{\mathrm{ab}}$ & $8.73^{\mathrm{b}}$ & $8.72^{\mathrm{b}}$ & 0.05 \\
\hline \multicolumn{6}{|l|}{ Pores in $0.25 \mathrm{~cm}^{2}$ of eggshell } \\
\hline sharp end & $11.7^{\mathrm{c}}$ & $15.4^{\mathrm{b}}$ & $17.6^{\mathrm{a}}$ & $16.8^{\mathrm{ab}}$ & 0.70 \\
\hline equatorial part & $14.8^{\mathrm{c}}$ & $16.2^{\mathrm{c}}$ & $22.7^{\mathrm{a}}$ & $20.5^{\mathrm{b}}$ & 0.73 \\
\hline blunt end & $24.8^{\mathrm{c}}$ & $27.6^{\mathrm{bc}}$ & $31.0^{\mathrm{b}}$ & $39.7^{\mathrm{a}}$ & 1.43 \\
\hline Blood and meat spots, $\%^{1}$ & 58.3 & 33.3 & 41.7 & 33.3 & - \\
\hline
\end{tabular}

SEM - standard error of means

abc - mean values in rows followed by different letters differ significantly $(\mathrm{P}<0.05)$

- statistical analysis was not performed 
goose eggs at 14 weeks of laying, compared to 2 weeks of laying, percentages of water, protein and ash were significantly higher. Time $\times$ groups interactions were also shown for ash percentage in yolk and water and ash percentage in white.

\section{DISCUSSION}

The highest egg production (37 eggs) and egg weight (192.4 g) were characteristic of crossbred geese from Sl'GrWK geese. In the same three-breed crosses, the number of eggs (20) and egg weight (145.3-152.1 g) were small in the first period of laying (Mazanowski et al., 2002), whereas in the second and third periods wild Graylag crosses of all groups laid more eggs that were heavier (Mazanowski and Bernacki, 2003; Mazanowski and Dziadek, 2003). The small egg production during the first year of laying may be attributed to slower sexual maturation of the wild Graylag crossbred geese (Cheng et al., 2003). Egg production in geese can also be increased by breeding methods. As a result of 13year selection, Schneider (1987) increased egg production by 8 eggs. Shalev et al. (1991) found an annual breeding progress of 2.7 eggs in a flock of geese.

Values of reproductive traits, including egg production, egg weight and the parameters of egg fertility and gosling hatchability were closely related to weight gain or weight loss during reproduction. Weight loss was lowest in crossbreds GrWK'Sl $-6.2 \%$ for ganders, and $13.7 \%$ for geese. The greatest body weight of ganders and geese was found in the crossbreds Sl'GrWK. These crossbreds showed small weight losses during reproduction and the greatest egg production and egg weight. Ganders and geese WKGr'Sl had the lowest body weight of all the birds, and females of this group were characterized by a considerable weight loss (20.4\%) during reproduction and by the greatest egg fertility and highest hatchability of goslings from fertilized eggs. The high weight loss in females from groups WKGr'Sl and $\mathrm{Sl}^{\prime} \mathrm{WKGr}$ had an unfavourable effect on the number and weight of eggs, and in group $\mathrm{Sl}^{\prime} \mathrm{WKGr}$ also on egg fertilization and gosling hatchability.

In the third period of egg production, the body weight of ganders and geese decreased considerably in groups without a clear effect on the reproductive traits (Mazanowski and Bernacki, 2003). In the present experiment, it was shown that the high body weight of ganders had an unfavourable effect on egg fertility and, indirectly, on the number of goslings hatched. The clear decrease in body weight of females during reproduction had a negative effect on the number and weight of their eggs but was beneficial for the indicators of hatchability.

In the present experiment, egg weight at the peak of laying was highest in GrWK'Sl geese, in which the loss of body weight was the lowest in the reproductive period, and lowest in Sl'WKGr, in which the loss of body weight was 
the highest. Egg shape indices were high and similar to those reported previously (Mazanowski and Bernacki, 2003). Eggshell area was lowest in Sl'WKGr geese compared to the other groups, in which egg weight and shell area were greater.

A similar tendency was reported earlier (Mazanowski and Bernacki, 2003). In the present experiment, eggshell thickness was high and did not differ significantly among the groups. In White Koluda geese, shell thickness was lower, ranging from 0.581 to $0.607 \mathrm{~mm}$ (Rosiński, 2000), and in Biłgoraj geese it was only $0.560 \mathrm{~mm}$ (Puchajda, 1991). The other shell traits and percentage of yolk, white and shell in egg did not differ significantly among the groups. In the earlier experiments, yolk and shell percentage in eggs was lower and that of white higher than in the present experiment (Mazanowski and Bernacki, 2003).

Yolk index assumed the highest and similar values in the geese from GrWK'Sl and Sl'GrWK, and Haugh units were the highest in WKGr'Sl geese. A positive correlation was found between Haugh units and the number of healthy goslings hatched per goose in groups Sl'GrWK and WKGr'Sl. In White Kołuda geese Rosiński (2000) reported higher Haugh units than in our experiment but the egg weight was lower. Values of yolk and white $\mathrm{pH}$ were significantly higher in the geese from group GrWK'S1, and lower in the others. In an earlier experiment, the mean $\mathrm{pH}$ values of the yolk of goose eggs in groups were lower, and the $\mathrm{pH}$ values of white in the experimental groups were similar to or slightly lower than those obtained in this experiment (Mazanowski and Bernacki, 2003). A positive relationship was found between egg quality and the number of goslings hatched per goose (groups Sl'GrWK and WKGr'Sl).

The lowest number of pores in eggshell was found in group GrWK'S1, and the highest in group WKGr'Sl. The large number of shell pores may result in better gas exchange and probably in the more intense radiation of heat, leading to lower mortality and better hatches of healthy goslings from set and fertilized eggs.

The levels of water, protein, fat and ash in the egg yolk of crossbred geese did not differ significantly among the groups. The exception was ash percentage which at 14 weeks of laying was significantly higher in the yolk of geese from group WKGr'Sl and the lowest in groups GrWK'Sl and Sl'GrWK. The level of crude protein in the yolks of Biłgoraj geese (Puchajda, 1991) was, \%: 16.9; crude fat, 35.8, ash, 1.8, and water 43.8, therefore they had a similar chemical composition to the yolks of eggs from the wild Graylag crosses. Ash was the only component that was lower in the yolk of Biłgoraj geese compared to crossbred Graylag geese (2.6-3.7\%). In yolks of geese, statistically significant increases during reproduction in water and ash content, and a decrease in ash percentage, were found in all the groups.

The chemical composition of the white of eggs from crossbred geese did not differ in protein content among the groups, either at 2 or 14 weeks of laying, in 
water content at 14 weeks, or in ash content at 2 weeks. The protein content of egg white in Biłgoraj geese was $9.8 \%$, the ash content $0.6 \%$, and the water content 90.2\% (Puchajda, 1991). In Biłgoraj geese, water content was higher than in crossbred geese in this experiment. In the white of the eggs of crossbred geese, there were statistically significant increases in the levels of water, protein and ash in all the experimental groups.

From 2 to 14 weeks of laying, the levels of water and ash increased, and the level of fat decreased in the egg yolks of geese from all the groups. However, a significant time $\times$ groups interaction only occurred for ash percentage. In the white of eggs, the levels of water, protein and ash also increased, but a significant time $\times$ groups interaction was only stated for water and ash percentage. Based on the results obtained, we suggest that changes might be necessary in goose egg incubation technology, i.e. increased incubation temperature during the final period of reproduction and slightly increased water evaporation from the egg surface due to increased egg water level during reproduction.

\section{CONCLUSIONS}

The greatest egg production, egg weight and body weight were characteristic of the Sl'GrWK hybrids (Slovakian male, Graylag $\times$ White Koluda female). The eggs of these geese were characterized by high yolk density, high yolk index and greater Haugh units than in the other groups. The mutually crossed WKGr'S1 hybrids (White Kołuda $\times$ Graylag male, Slovakian female) with the lowest body weight showed the greatest egg fertility and hatchability of goslings from set and fertilized eggs. In addition, they were characterized by a higher Haugh unit value than in the other groups and by the greatest number of pores in the shell. The eggs of WKGr'Sl hybrids contained the greatest amount of ash in yolk at the end of the laying period and the greatest amount of water in white at the beginning of the laying period. Sl'GrWK and WKGr'Sl crosses could be used in further work on goose breeding.

During the egg production period, the water and ash content of yolks increased, and the fat content decreased regardless of the direction of crossing of the parents. A statistically significant interaction (time $\times$ groups) was only found for ash percentage. During the same period, there were increases in the water, protein and ash content of the white, but the time $\times$ groups interaction only occurred for water and ash percentage. 


\section{REFERENCES}

Cheng Y.S., Rouvier R., Hu Y.H., Tai J.J., Tai C., 2003. Breeding and genetics of waterfowl. World Poultry Sci. J. 59, 509-519

Kiełczewski K., 1992. Package of Statistical Computer Programs. National Research Institute of Animal Production (in Polish). Zakrzewo (Poland)

Mazanowski A., 2001. Effect of reciprocal crossing of White Kołuda and greylag ganders of geese with Slovakian on meat traits of progeny (in Polish). Rocz. Nauk. Zoot. 28 (2), 59-76

Mazanowski A., Adamski M., 2002. Evaluation of reproductive traits and egg quality in Astra G geese during the first reproductive period. Ann. Anim. Sci. 2, 67-78

Mazanowski A., Bernacki Z., 2003. Comparing reproductive performance and egg quality of triple crosses with graylag goose (in Polish). Rocz. Nauk. Zoot. 30 (1), 171-184

Mazanowski A., Chełmońska B., 2000. The effects of reciprocal crossing of White Kołuda and graylag crossbredgeese with Slovakian geese. Ann. Anim. Sci. - Rocz. Nauk. Zoot. 27 (4), 85-103

Mazanowski A., Dziadek K., 2003. Traits of Graylag, White Kołuda and Slovakian goose crossbreds relative to direction of crossing. Ann. Anim. Sci. 3, 165-183

Mazanowski A., Dziadek K., Adamski M., 2002. Reproductive and meat traits of triple crosses with Graylag geese (in Polish). Rocz. Nauk. Zoot. 29 (1), 105-120

Mazanowski A., Kiełczewski K., 1999. Reproductive performance of geese from genetic reserve flocks and White Kołuda geese in two laying periods (in Polish). Rocz. Nauk. Zoot. 26 (1), 55-72

Paganelli C.V., Olszowka A., Ar A., 1974. The avian egg: surface area, volume and density. Condor $76,319-325$

Puchajda H., 1991. Productive traits and their genetic parameters in conservative herd of Bilgoray geese (in Polish). Acta Acad. Agr. Tech. Olst., Zoot. 34, 3-59

Ramos M., Puentes D., Jay M., Tandron E., Toledo Y.E., 1991. Morphological, physical and chemical traits of goose egg in tropical conditions. 2. The effect of egg shell thickness on losses during incubation in Landes geese. Rev. Cubana Avic. 18, 175-178

Romanov M.N., 1999. Goose production efficiency as influenced by genotype, nutrition and production systems. World Poultry Sci. J. 55, 281-294

Rosiński A., 2000. Analysis of direct and correlated effects of selection in two goose strains. Rocz. Akad. Roln. Pozn. 309, 5-107

Schneider K.H., 1987. Erhöhung der Legeleistung bei Gänsen durch eine effektive Selektion auf Eizahl. Tierzucht 41, 416-418

Shalev B.A., Dvorin A., Herman R., Katz Z., Bornstein S., 1991. Long-term goose breeding for egg production and crammed liver weight. Brit. Poultry Sci. 34, 703-709

Williams K.C., 1997. Some factors affecting albumen quality with particular reference to Haugh unit score. World Poultry Sci. J. 48, 5-16 


\section{STRESZCZENIE}

\section{Charakterystyka cech reprodukcyjnych i cech jaj gęsi mieszańców z udziałem gęsi gęgawych}

Celem pracy była ocena cech reprodukcyjnych i cech fizycznych jaj, mieszańców potrójnych gęsi białych kołudzkich, słowackich i gęgawych, w zależności od kierunku krzyżowania komponentów rodzicielskich oraz określenie różnic w składzie chemicznym jaj na początku i na końcu okresu reprodukcji.

Największa nieśność, masa jaj i masa ciała cechowały mieszańce Sl'GrWK (samiec słowacki, samica mieszaniec gęgawy z białą kołudzką). Żółtka jaj tych gęsi wyróżniała duża gęstość i wysoki indeks oraz wyższa niż w innych grupach wartość jednostek haugha. Mieszańce WKGr'Sl (samiec mieszaniec białej kołudzkiej z gęgawą, samica słowacka) o najmniejszej masie ciała, krzyżowane między sobą miały największe zapłodnienie jaj oraz wylęg piskląt z jaj nałożonych i zapłodnionych. Poza tym wyróżniała je wyższa niż w innych grupach wartość jednostek Haugha oraz największa liczba porów w skorupie jaj. Jaja mieszańców WKGr'Sl miały w żółtku najwięcej popiołu na końcu nieśności, a w białku na początku nieśności najwięcej wody. Mieszańce Sl'GrWK i WKGr'Sl można wykorzystać w dalszych pracach na gęsiach.

W okresie nieśności zwiększyła się w żółtkach jaj gęsi zawartość wody i popiołu, a zmniejszyła zawartość tłuszczu, niezależnie od kierunku krzyżowania komponentów rodzicielskich. Statystycznie istotną interakcję (czas $\times$ grupy) stwierdzono tylko w procentowym udziale popiołu. W tym samym czasie w białku jaj gęsi zwiększyła się zawartość wody, białka i popiołu, ale interakcja (czas x grupy) była tylko w procentowym udziale wody i popiołu. 